\title{
Hubungan Kejadian Internet Addiction dengan Prestasi Belajar pada Mahasiswa FK Unand
}

\author{
Rizky Erizka ${ }^{1}$, Nadjmir ${ }^{2}$, Elly Usman ${ }^{3}$
}

\begin{abstract}
Abstrak
Teknologi internet berkembang sangat pesat dalam beberapa tahun terakhir dengan berbagai manfaat positif dan negatifnya. Internet addiction merupakan salah satu dampak negatif yang ditimbulkan. Dalam beberapa penelitian disebutkan pengaruh internet addiction terhadap beberapa aspek termasuk pendidikan. Tujuan penelitian ini adalah mengetahui angka kejadian internet addiction dan mempelajari hubungannya dengan prestasi belajar pada mahasiswa Fakultas Kedokteran Unand. Metode studi cross sectional dilakukan terhadap mahasiswa FK Unand angkatan 2011. Hasil penelitian diolah dengan menggunakan uji chi-square. Hasil penelitian menunjukkan kejadian internet addiction mempengaruhi prestasi belajar pada mahasiswa FK Unand. Sebanyak 1,1\% subjek mengalami internet addiction berat, $34,4 \%$ sedang dan $37,7 \%$ ringan. Berdasarkan jenis kelamin perempuan lebih banyak mengalami internet addiction daripada laki laki karena perempuan yang lebih banyak. Klasifikasi yang terbanyak adalah cyber-relationship dan metode paling banyak yang digunakan untuk mengakses internet adalah dengan menggunakan smartphone. Hasil lain yang didapatkan adalah kebutuhan dasar dan ibadah adalah kegiatan paling dominan yang dapat menghentikan responden dari mengakses internet. Disimpulkan bahwa kejadian internet addiction mempengaruhi prestasi belajar pada mahasiswa FK Unand.
\end{abstract}

Kata kunci: cyber-relationship, internet, internet addiction, prestasi belajar

\section{Abstract}

The internet technology grow very fast in recent years bringing many positive and negative effects. Internet addiction is one of the negative effect. Several research confirm some negative effect of internet addiction including academic problem. The objective of this study was to know frequency and it's relation with academic achievement in Medical Faculty of Andalas university's students. This was a cross-sectional study on Medical Faculty of Andalas University's students. The result were analyzed by chi-square test. Based on the analyzed result, it confirm that the internet addiction cause problems in academic achievement. 1.1\% samples suffer the severe internet addiction, intermediate $34.4 \%$ and mild $37.7 \%$. By gender, more females suffer the internet addiction than males because there were more female than male. Based on classification, samples tends to suffer the Cyber-Relationship types of Internet addiction and most of them use smartphone to gain access to the internet. Basic needs and religion needs were the most activities that can stop the internet access. It can be conclude that internet addiction can cause problem in academic.

Keywords: academic achievement, cyber-relationship, internet, internet addiction

Affiliasi penulis:1. Prodi Profesi Dokter FK UNAND (Fakultas Kedokteran Universitas Andalas Padang), 2. Bagian IImu Psikiatri FK UNAND/RSUP Dr. M. Djamil, Padang, 3. Bagian Farmakologi FK UNAND.

Korespondensi: Rizky Erizka, Email: rizky.erizka@gmail.com Telp: 085278295433

\section{PENDAHULUAN}

Teknologi internet berkembang sangat pesat dalam beberapa tahun terakhir dan telah memasuki berbagai sektor kehidupan. Perkembangan yang sangat pesat ini memicu angka penggunaan internet 
yang sangat tinggi di berbagai negara. Berdasarkan laporan World Internet Project, lima dari enam negara responden melaporkan angka akses diatas $60 \%$ dari total populasi. ${ }^{1}$ Laporan penelitian lain menyebutkan penggunaan di kalangan remaja yang sangat tinggi. ${ }^{2}$

Tingginya angka akses internet ini diikuti oleh berbagai dampak positif dan negatif terhadap masyarakat. Salah satunya adalah internet addiction yang menggambarkan penggunaan internet secara berlebihan dan kemudian menimbulkan berbagai masalah pada berbagai sektor. ${ }^{3}$

Internet addiction digolongkan ke dalam bentuk behavioral addiction yang merujuk ke kegagalan individu untuk mengontrol keinginan secara berlebihan sehingga menimbulkan permasalahan terhadap hal hal yang seharusnya dilakukan oleh individu tersebut. ${ }^{4}$

Salah satu sektor yang berkaitan dengan internet addiction ini adalah proses pendidikan. Hal ini terjadi akibat integrasi fasilitas internet ke dalam sarana prasarana pendidikan. Sebuah survey di lingkungan Alfred University Amerika Serikat menunjukkan bahwa 43\% dari mahasiswa mereka yang mengalami kemunduran prestasi belajar, menggunakan internet hingga larut malam. Penelitian lain menyebutkan bahwa $86 \%$ civitas akademik menyatakan bahwa penggunaan internet dalam lingkungan pendidikan tidak memberikan efek positif terhadap performa akademik. ${ }^{5}$ Hal ini berkaitan dengan banyaknya informasi dan fasilitas yang tersedia sehingga dapat menjadi pengalih perhatian mahasiswa dari tujuan belajar. 58\% mahasiswa dilaporkan mengalami penurunan kebiasaan belajar, penurunan performa akademik dan tidak masuk kelas akibat menggunakan internet. ${ }^{6} \mathrm{Hal}$ ini sesuai dengan penelitian di Turki yang menunjukkan bahwa tingkat keparahan internet berbanding lurus dengan perburukan prestasi belajar. $^{7}$

Hasil penelitian pendahuluan yang dilakukan di lingkungan Fakultas Kedokteran Universitas Andalas (FK Unand) terhadap 30 orang mahasiswa angkatan 2011 menunjukkan bahwa 96.7\% responden memiliki akses pribadi terhadap internet. 57\% diantaranya menggunakan internet lebih dominan untuk kepentingan diluar pendidikan. Hasil lain yang didapatkan yaitu waktu akses rata-rata responden antara 6 hingga 7 jam dan beberapa diantaranya mengakses internet dengan waktu lebih dari 12 jam dalam sehari.

Berdasarkan penjabaran tersebut, maka perlu dilakukan penelitian mengenai hubungan antara kejadian internet addiction dengan prestasi belajar pada mahasiswa FK Unand.

\section{METODE}

Penelitian ini adalah studi observasional dengan desain cross sectional terhadap populasi mahasiswa FK Unand angkatan 2011.

Pengambilan data dilakukan pada Juni 2014 dengan total populasi adalah sebanyak 297 orang dengan metode pengambilan sampel menggunakan total sampling dan sampel minimal pada derajat kepercayaan 95\% adalah sebanyak 170 orang.

Data penelitian didapatkan melalui kuesioner yang terdiri dari 2 bagian. Bagian pertama berisi data umum yang berkaitan dengan informasi prestasi akademik mahasiswa dan bagian kedua menggunakan kuesioner Internet Addiction Test (IAT) yang telah ditambahkan terjemahan teks berbahasa Indonesia setelah teks asli berbahasa Inggris untuk mendapatkan informasi tingkat keparahan internet addiction. Analisa data dilakukan secara bertahap yaitu analisa univariat dan analisa bivariat menggunakan chi-square test.

\section{HASIL}

Setelah dilakukan proses pengambilan data, didapatkan 192 mahasiswa FK Unand angkatan 2011 yang mengisi dan mengembalikan kuesioner. Sebanyak 183 diantaranya memenuhi kriteria untuk dilakukan pengolahan data.

\section{Gambaran kejadian internet addiction berdasarkan jenis kelamin}

Tabel 1. Gambaran kejadian internet addiction berdasarkan jenis kelamin

\begin{tabular}{ccccc}
\hline \multirow{2}{*}{$\begin{array}{c}\text { Jenis } \\
\text { Kelamin }\end{array}$} & \multicolumn{4}{c}{ Internet Addiction Test } \\
\cline { 2 - 5 } & Normal & Ringan & Sedang & Berat \\
\hline $\mathrm{L}$ & 22 & 21 & 22 & 2 \\
$\mathrm{P}$ & 27 & 48 & 41 & 0 \\
\hline
\end{tabular}


Berdasarkan Tabel 1, didapatkan bahwa angka kejadian internet addiction lebih tinggi pada responden perempuan yaitu sebanyak 48 orang perempuan mengalami internet addiction ringan dan 41 orang mengalami internet addiction sedang akibat populasi perempuan yang lebih banyak.

\section{Gambaran kejadian internet addiction berdasarkan} klasifikasi internet addiction

Tabel 2. Gambaran kejadian internet addiction berdasarkan klasifikasi

\begin{tabular}{lcccc}
\hline \multicolumn{1}{c}{$\begin{array}{c}\text { Klasifikasi } \\
\text { internet } \\
\text { addiction }\end{array}$} & \multicolumn{4}{c}{ Internet Addiction Test } \\
\cline { 2 - 5 } & Normal & Ringan & Sedang & Berat \\
\hline Cyber-sexsual & 0 & 2 & 0 & 0 \\
$\begin{array}{l}\text { Computer } \\
\text { addiction }\end{array}$ & 1 & 5 & 2 & 0 \\
$\begin{array}{l}\text { Net Compulsion } \\
\text { Information }\end{array}$ & 1 & 0 & 2 & 0 \\
$\begin{array}{l}\text { Overload } \\
\text { Cyber }\end{array}$ & 27 & 32 & 24 & 0 \\
Relationship & 20 & 30 & 35 & 2 \\
\hline
\end{tabular}

Berdasarkan Tabel 2, didapatkan bahwa klasifikasi internet addiction yang kejadiannya tinggi yaitu cyber relationship atau penggunaan media sosial dimana 30 orang mengalami internet addiction ringan, 35 orang mengalami internet addiction sedang dan 2 orang mengalami internet addiction berat. Sedangkan untuk information overload atau pencarian informasi berlebihan didapatkan sebanyak 32 orang mengalami internet addiction ringan dan 24 orang mengalami internet addiction sedang.

Gambaran kejadian internet addiction berdasarkan metode mengakses internet

Tabel 3. Gambaran kejadian internet addiction berdasarkan metode mengakses internet

\begin{tabular}{lcccc}
\hline \multicolumn{1}{c}{$\begin{array}{c}\text { Metode } \\
\text { Akses } \\
\text { Internet }\end{array}$} & \multicolumn{4}{c}{ Internet Addiction Test } \\
\cline { 2 - 5 } & Normal & Ringan & Sedang & Berat \\
\hline Laptop/PC & 16 & 27 & 21 & 2 \\
PC publicl & 3 & 0 & 0 & 0 \\
Warnet & & & & \\
Smartphone & 22 & 31 & 27 & 0 \\
Tablet/ipad & 9 & 11 & 15 & 15 \\
\hline
\end{tabular}

Berdasarkan Tabel 3 ditemukan bahwa penggunaan smartphone merupakan metode akses internet yang terlibat paling banyak untuk kejadian internet addiction. Sebanyak 31 orang mengalami internet addiction ringan dan 27 orang mengalami internet addiction sedang.

\section{Hal yang dapat menghentikan akses internet}

Tabel 4. Gambaran hal yang dapat menghentikan akses internet

\begin{tabular}{lc}
\hline \multicolumn{1}{c}{ Aktivitas } & f \\
\hline Aktivitas Sosial & 19 \\
Belajar & 23 \\
Ibadah & 66 \\
Kebutuhan Dasar & 56 \\
Kuliah & 14 \\
Lainnya & 5
\end{tabular}

Berdasarkan Tabel 4 didapatkan bahwa aktivitas paling dominan yang dapat menghentikan seseorang dari mengakses internet adalah ibadah.

\section{Hubungan kejadian internet addiction dengan prestasi belajar}

Tabel 5. Hubungan kejadian internet addiction dengan prestasi belajar

\begin{tabular}{lccccc}
\hline \multirow{2}{*}{$\begin{array}{l}\text { Internet } \\
\text { Addiction }\end{array}$} & \multicolumn{5}{c}{ Prestasi Belajar } \\
\cline { 2 - 5 } & $\begin{array}{l}\text { Kelompok } \\
\text { Tertinggi }\end{array}$ & $\begin{array}{l}\text { Kelompok } \\
\text { Sedang }\end{array}$ & $\begin{array}{l}\text { Kelompok } \\
\text { Terendah }\end{array}$ & Total & $\mathbf{p}$ \\
\hline $\begin{array}{l}\text { Normal }- \\
\text { Ringan }\end{array}$ & 14 & 98 & 6 & 118 & \\
$\begin{array}{l}\text { Sedang }- \\
\text { Berat }\end{array}$ & 4 & 51 & 10 & 65 & 0.037 \\
\hline Total & 18 & 149 & 16 & 183 & \\
\hline
\end{tabular}

Pada Tabel 5 berdasarkan uji chi-square didapatkan bahwa nilai $p$ sebesar $0.037(p<0.05)$. Hal ini menunjukkan bahwa terdapat hubungan antara kejadian internet addiction dengan prestasi belajar pada mahasiswa FK Unand.

\section{PEMBAHASAN}

Berdasakan hasil pengolahan data didapatkan bahwa lebih banyak perempuan mengalami internet addiction karena populasi perempuan yang menjadi subjek menelitian lebih besar. Mayoritas subjek 
mengalami internet addiction ringan hingga sedang. Hasil ini sesuai dengan penelitian oleh Sally (2006) yang menunjukkan bahwa lebih banyak perempuan mengalami internet addiction. Dalam penelitian tersebut dinyatakan bahwa jenis kelamin mempengaruhi kejadian internet addiction. ${ }^{8}$

Hasil mengenai gambaran kejadian internet addiction berdasarkan klasifikasi menunjukkan bahwa cyber-relationship seperti penggunaan media sosial dan information overload menjadi bagian yang paling dominan. Hasil ini sesuai dengan penelitian Sally yang menunjukkan bahwa penggunaan media sosial mempengaruhi angka kejadian internet addiction. ${ }^{8}$

Tingginya kejadian cyber-relationship terutama penggunaan media sosial ini dapat dihubungkan dengan kejadian Fear Of Missing Out (FOMO) yang dikemukakan oleh Przybylski et al (2013) yang menyatakan bahwa FOMO menyebabkan seseorang memiliki keinginan kuat untuk mengikuti secara berkelanjutan aktivitas yang dilakukan orang lain. ${ }^{9}$

Hasil berikutnya menunjukkan bahwa penggunaan smartphone merupakan metode akses internet paling dominan. Hal ini disebabkan oleh kemudahan penggunaan dan mobilitas yang tinggi dari perangkat tersebut. Selain smartphone, penggunaan PC/Laptop pribadi juga menunjukkan angka penggunaan yang tinggi. Hasil ini dikonformasi oleh penelitian yang dilakukan Choi et al (2012) yang menyatakan bahwa penggunaan smartphone berlebihan dapat mengganggu kesehatan mental, kehidupan kampus dan keluarga. ${ }^{10}$

Aktivitas yang dapat menghentikan akses internet ialah ibadah yang menjadi aktivitas yang paling dominan. Sedangkan aktivitas kuliah dan belajar tidak terlalu berkontribusi untuk menghentikan seseorang dari mengakses internet.

Hasil pengolahan multivariat menunjukkan bahwa tingkat keparahan internet addiction berbanding lurus dengan perburukan prestasi belajar dengan nilai $p=0.037(<0.05)$. Hasil ini sesuai dengan penelitian Sally yang menyatakan bahwa internet addiction merupakan salah satu faktor yang dapat menyebabkan penurunan prestasi belajar. ${ }^{8}$ Hasil ini juga sesuai dengan penjelasan Slameto (2005) bahwa pengaruh faktor lingkungan, yang salah satunya adalah akses internet berlebihan dapat menyebabkan kelelahan fisik dan pengalihan perhatian, sehingga mempengaruhi prestasi belajar. ${ }^{11}$

Penelitian lain oleh Mukodim et al (2004) menunjukkan bahwa internet addiction tidak memberikan pengaruh yang signifikan terharap prestasi belajar. Hal ini terjadi karena dalam penelitiannya Mukodim menemukan angka kejadian internet addiction yang rendah. Akses paling dominan adalah untuk kepentingan pekerjaan dan pendidikan dengan durasi penggunaan yang relatif pendek. ${ }^{12}$

\section{KESIMPULAN}

Terdapat hubungan antara kejadian internet addiction dengan prestasi belajar, yaitu peningkatan keparahan internet addiction berbanding lurus dengan perburukan prestasi belajar.

\section{DAFTAR PUSTAKA}

1. World Internet Project. World internet project international report. California: University of Sourthern California; 2013.

2. Ayas T, Horzum B. Relation between derpression, loneliness, self-esteem and internet addiction. Education. 2013;133(3):280-90.

3. Soetjipto, Helly P. Pengujian konstruk kriteria kecanduan internet. Jurnal Psikologi Fakultas Psikologi UGM. 2005;32(2):74-91.

4. Sussman S, Moran MB. Hidden addiction: television. Journal of Behavioral Addictions. 2013; 2(3):125-32.

5. Young KS. Internet addiction: the emerge of a new clinical disorder. Cyber Psychology and Behavior. 1996;1(3):237-44.

6. Young KS. Internet addiction: symptoms, evaluation, and treatment. Dalam: Vande Creek L, Jackson T, editor (penyunting). Innovation in clinical practice: a source book. Sarasota FL: Professional Resource Press; 1999. hlm.19-31.

7. Gencer, S. L., \& Koc, M. Internet Abuse among Teenagers and Its Relationship to Internet Usage Patterns and Demographics. Educational Tecnology \& Society. 2013; 15(2):hal.25-36.

8. Sally LP. Prediction of internet addiction for undergraduates in Hong Kong. (dissertation). Hong Kong: Hong Kong Baptist University; 2006. 
9. Przybylski AK, Murayama K, DeHaan CR, Gladwell V. Motivational, emotional, and behavioral correlates of fear of missing out. Computers in Human Behavior. 2013;29(4):1841-8.

10. Choi HS, Lee HK, Ha JC. The influence of smartphone addiction on mental health, campus life and personal relations-focusing on $\mathrm{K}$ university students. Journal of the Korean Data and Information Science Society. 2012; 23(5):1005-15.
11. Slameto. Belajar dan faktor-faktor yang mempengaruhi. Jakarta: Rineka Cipta; 2005.

12. Mukodim D, Ritandiyono, Sita HR. Peranan kesepian dan kecenderungan internet addiction disorder terhadap prestasi belajar mahasiswa Universitas Gunadarma. Proceedings Komputer dan Sistem Intelejen (KOMMIT2004). 2004 Aug 24-25, Jakarta: Komputer dan Sistem Intelejen; 2004.hlm.111-20. 